\title{
Destinasyonlarda Konaklama Hizmet Kalitesi Ölçümü: Safranbolu Örneği
}

\author{
Ahmet Gürbüz \\ Karabük Üniversitesi \\ İktisadi ve İdari Bilimler Fakültesi \\ orcid.org/0000-0003-2287-9709
}

\author{
Nurettin Ayaz \\ Karabük Üniversitesi \\ Safranbolu Turizm Fakültesi \\ orcid.org/0000-0003-2117-2015
}

\author{
Hanife Ölçer* \\ Karabük Üniversitesi \\ Sosyal Bilimler Enstitüsü \\ orcid.org/0000-0002-9574-1172
}

Gönderilme Tarihi 07.05.2019

Kabul Tarihi 18.07.2019

\section{$\ddot{O} z$}

Turizm sektöründe turistler için vazgeçilmez bir gereklilik olan konaklama hizmeti, sektördeki işletmelerin önemli kazanç alanlarından biridir. Bu anlamda konaklama hizmetine yönelik araştırmalar, müşteri memnuniyetini artırma ve sektörel kazancı artırmada önemli çalışmalardır. Bu araştırma, destinasyonda sunulan konaklama hizmetlerine katkı sağlamak düşüncesiyle gerçekleştirilmiştir. Araştırmada önemli bir kültür turizmi varış noktası olan ve UNESCO Dünya Miras Listesi içerisinde yer alan Safranbolu'da faaliyet gösteren konaklama işletmelerinden beklenen ve algilanan hizmet kalitesinin belirlenmesi amaçlanmıştır. Bu amaçla Ocak-Haziran 2018 döneminde Safranbolu'yu ziyaret eden 406 yerli turistten anket tekniği ile veri toplanmıştır. Anket verilerinin analizi sonucunda hizmet kalitesine yönelik fiziksel özellikler, güven, yeterlilik, güvenilirlik ve heveslilik olmak üzere, konaklama hizmetlerine yönelik beş boyut belirlenmiştir. Bu boyutlar, ziyaretçilerin demografik ve diğer özellikleri ile "bağımsız örneklemler için t-testi" ve "tek faktörlü varyans analizi" kullanılarak karşılaştırılmıştır. Ayrıca Safranbolu destinasyonundaki konaklama hizmetleri için beklenen ve algılanan hizmet kalitesine yönelik SERVQUAL skoru hesaplanmıştır. Safranbolu destinasyonundaki konaklama hizmetlerindeki beklenen hizmet kalitesi ve alglanan hizmet kalitesi arasinda -1,09 SERVQUAL skoruna ulaşılmıştır. Araştırmada ayrıca, gelecekte Safranbolu destinasyonunda sunulacak konaklama hizmetlerinin niteliğinin artırlmasına yönelik öneriler geliştirilmiştir.

Anahtar Kelimeler: Hizmet, Hizmet Kalitesi, Turizm, Konaklama İşletmeleri, Safranbolu.

\section{The Measurement of Accommodation Service Quality in Destinations: The Case of Safranbolu}

\begin{abstract}
Accommodation service, which is an indispensable requirement for tourists in the tourism sector, is one of the important commercial businesses in the sector. In this sense, researches on accommodation services are important in increasing customer satisfaction and sectoral gain. This research was carried out with the aim of contributing to the accommodation services offered in destinations. The aim of the study was to determine the expected and perceived service quality of the accommodation establishments operating in Safranbolu, which is an important cultural tourism destination listed in the UNESCO World Heritage List. For this purpose, data were collected from 406 local tourists who visited Safranbolu between January-June 2018. In the research, five dimensions were determined, physical characteristics of service quality, confidence, competence, reliability and enthusiasm. These dimensions were compared according to the demographic variables of the visitors by using $t$ t-test for independent samples and analysis of variance. In addition, SERVQUAL score was calculated for expected and perceived service quality
\end{abstract}


for accommodation services in Safranbolu destination. SERVQUAL score of -1.09 was determined between expected service quality and perceived service quality in accommodation services in Safranbolu. In addition, recommendations were made to improve the quality of accommodation services.

Keywords: Service, Service Quality, Tourism, Hospitality Industry, Safranbolu.

\section{Giriş}

Küreselleşmenin ortaya çıkardığı artan rekabetten etkilenen kurumlar arasında konaklama işletmeleri de yer almaktadır. Konaklama işletmeleri, rekabet ortamında varlıklarının devamını sağlama ve karlılıklarını garanti edebilme adına müşteri odaklı stratejiler kapsamında hizmet kalitesi ölçümlemelerine başvurmak zorunda olan kurumlardır.

İşletmelerin varlığının temel dinamiği olan tüketiciler, karmaşık bir yapıya sahiptir. Bu kapsamda tüketicilere bir ürün veya hizmet sunulurken pazarlamacilar mamullerine uygun bir hedef pazar seçme, hedef pazarı detaylı bir şekilde analiz etme ve ürün, pazar, fiyat ve tutundurmadan oluşan pazarlama karması elemanları perspektifinde bir pazarlama planı oluşturmadırlar. Ancak bu planlarda hizmetlerin somut ürünlere göre daha ayrıntılı düşünülmesi gerekir (Üner, 1994: 2-11). Bu kapsamda bireylerin ekonomik ürünleri veya hizmetleri satın alma ve kullanımı ile ilişkilendirilen tüketici davranışına (Odabaşı ve Barış, 2002: 8) başvurulması gerekir.

Kaliteli hizmet adına hizmet talep eden tüketicilerin hizmet kalitesine yönelik öncelik kriterlerini bilmek önem arz eder (Arslantürk, Altunöz ve Çalık, 2013: 109). Özellikle emek yoğun bir sektör olarak kabul edilen turizmde hizmet sunan işletmeler için kalite algısı; müşterilerin sosyo demografik özellikleri ve beklentileri ile işletmenin imajına göre değişebilmekte, bileşik ürün özelliği nedeniyle turizm işletmelerinin hizmet kalitesine yönelik memnuniyet derecesi değişebilmekte ve soyut bir kavram olarak hizmetin kalitesinin ölçülmesi zorlaşmaktadır (Kılıç ve Eleren, 2010: 121-122).

Konaklama sektöründe hizmet kalitesi, rekabetçi bir pazarda sürdürülebilir rekabet avantajı ve müşterilerin güvenini kazanmak için en önemli faktörlerden biri olup, kritik bir başarı faktörüdür (Al-Ababneh, 2017: 1). Hizmet kalitesi, turizm sektöründe kullanılan önemli bir standarttır. Müşterilerin imajını etkileme yönü bulunur. Destinasyonlara yönelik seyahatlerinde turistlerin imaj algılarl; tesisler, turistik yerler ve hizmet standartları arasındaki karşılaştırmaları içerir (Al-Ababneh, 2013: 165).

Hizmet kalitesine yönelik araştırmalar dünya genelinde artmaktadır. Bu durum, hizmet sektörünün ekonomi içindeki ağırlığı ile doğrudan ilişkilidir. Örneğin Türkiye ölçeğinde 2015 yılı itibariyle istatistiklerde hizmetler sektörünün büyümeye katkısı \%2,3 iken, inşaat sektörü de dahil olmak üzere sanayi sektörünün katkısı \%1,2 oranında kalmış, tarım sektörünün ise katkısının olmadığı saptanmıştır (Arakaya, 2016: 3). Bu veriler göstermektedir ki hizmetler, gelişmişliğin bir göstergesi olarak ekonomi üzerinde oldukça etkilidir. $\mathrm{Bu}$ nedenle hizmetlerin kalitesinin yükseltilebilmesi adına sürekli izlenmeleri ve geliştirilmeleri gerekmektedir. Özellikle 
tüketici beklentilerini karşılayabilme ve değişimlere cevap verebilme adına hizmet sunan işletmeler, hizmet talep eden müşterilerine odaklanmalıdırlar (Gürbüz ve Doğan, 2013: 240). Bu odaklanma sürecinde hizmet kalitesi ölçümlemeleri ise önemli bir gereklilik olarak görülebilir.

$\mathrm{Bu}$ araştırmada konaklama hizmet kalitesi destinasyon bazında ele alınmakta ve yerli turistlerin konaklama hizmetlerine yönelik beklenti ve algılarının ortaya konulması amaçlanmaktadır. Bu amaç doğrultusunda Dünya Mirası Listesi içerisinde tarihi mimari yapısı ile kültür turizmi adına önemli bir çekim merkezi olarak kabul edilen Safranbolu destinasyonu perspektifinden konaklama hizmetlerinin kalitesi üzerine bir bakış açısı geliştirilmesi öngörülmektedir.

\section{Konaklama İşletmeleri}

Konaklama (lodging) "bir konut içerisindeki bir veya birkaç odanin konut içinde yaşayan kişiler dışındaki kişilere kiralanması" olarak ifade edilmekle birlikte "kalınacak geçici yer", "bir yerde kalmak", "barınma” ve "geceleme için geçici bir yer" ifadeleri de konaklama kavramı ile özdeşleştirilmektedir (www.google.com.tr; www.dictionary.com; www.merriam-webster.com). Türk Dil Kurumu (TDK) ise konaklamayı "yolculuk sırasında bir yerde durup geçici bir süre kalmak" olarak açılamaktadır.

Turizm sektöründe konaklama; konukların geceleme, beslenme, eğlence vb. ihtiyaçlarını karşılayabilme özellikleri nedeniyle "konaklama sektörü" olarak da adlandırılmaktadır. Geçici olarak bir ücret karşılığında hizmet sunan otel, motel, pansiyon, bungalov, kamping, tatil köyü vb. işletmelerinin yer aldığı ve turistik mal ve hizmetlerin üretimini sağlandığı sektör olarak gösterilmektedir (Uyar, 2013: 16).

Konaklama işletmeleri, Turizm Yatırımları ve İşletmeleri Nitelikleri Yönetmeliği'nin 19. maddesinde "aslî fonksiyonları müşterilerin konaklama ihtiyaçlarını sağlamak olan, bu hizmetin yanında, yeme-içme, spor ve eğlence ihtiyaçları için yardımcı ve tamamlayıcı birimleri de bünyelerinde bulundurabilen tesisler" olarak gösterilmektedir (www.resmigazete.gov.tr). Bununla birlikte bu işletmeler, sağlamış oldukları hizmetleri ticari bir anlayış, kural ve uygulamalar neticesinde yerine getiren teknik birimlerdir (Özel, 2016: 6).

Bir konaklama işletmesinde kaliteli hizmet sunumunun ön koşulu, işlevsel ve fonksiyonel bir organizasyonel yapı oluşturmasıdır. Organizasyonel yapının şekillenmesinde konaklama işletmesinin büyüklüğü belirleyici öğedir. Fonksiyonel bir organizasyon yapısı; her bir alanın, çalışanların üretkenliğinin artırmasına ve görevlere odaklanılmasını sağlar. Kurum genelinde koordinasyon çabaları kolaylaşır. Her işlevsel alan, hedeflerini başarılı bir şekilde yerine getirebilir (http://smallbusiness.chron.com).

\section{Hizmet, Kalite ve Hizmet Kalitesi Ölçümü}

Küreselleşen dünyada, ekonominin gelişmesine ve sanayileşmesine paralel olarak hizmetlerin önemi ve payı hızla artmaktadır. Bu durumun temel sebepleri; hizmet sektörünün refah ve gelişmişlik seviyesinin bir göstergesi olması ve gelişen 
teknolojik gelişmelerin ortaya çıkarmış olduğu değişimlerin farklı hizmet türlerini de beraberinde getirmiş olmasıdır. Özellikle sağlık, eğitim, hukuk, finansman ve turizm gibi farklı alanlarda meydana gelen değişimler hizmet işletmelerinin çoğalmasına yol açmakta ve hizmet sektörünün önemi her geçen gün artmaktadır (Okumuş ve Duygun, 2008: 18).

Kalite, Latince "qualis" kelimesinden türetilmiş olup, "nasıl oluştuğu" anlamına gelmektedir. Türk Dil Kurumu (TDK) ise kaliteyi "vasıf, nitelik" olarak belirtmektedir. Bununla birlikte kalite, "standartlara uygunluk", "müşterilerin isteklerine uygunluk" olarak da düşünülmektedir (Aydıntan, 2012: 1). Kotler (2000: 57), kaliteyi "bir ürün veya hizmetin şekil ve özellikleri olup, belirlenen şeyleri yerine getirecek süreçlere sahip olması" olarak betimlemektedir. Deming tarafından "pazarın ihtiyaçların karşılayabilmek için düşük maliyet ile değişmezliğin ve güvenirliliğin tahmin edilebilmesi" ve Crosby tarafından "şartlara uygunluk" olarak" gösterilen kalite; "bir ürünün ya da hizmetin ihtiyaçları karşılayabilecek özelliklerin toplamı" olarak da ifade edilmektedir (Tütüncü, 2009: 63). Kaliteye yönelik diğer tanımlamalar; ISO 9000'e göre kalite; “bir ürün veya hizmetin tanımlanan ihtiyaçları karşılayabilme yetisine sahip özellikler" (Şimşek, 1998: 7). Juran'a göre kalite; “kullanıma uygunluk", Ishıkawa'ya göre kalite; "kontrol uygulamak; tüketiciyi tatmin edecek en kullanışl, en konforlu kaliteli ürünleri üretmek, tasarımını yapmak ve satış sonrası hizmetini gerçekleştirmek", Feigenbaum'a göre kalite; bir ürün ya da hizmetin değeri, Masaaki İmai'ye göre kalite; "iyileştirilebilen her şey" ISO 8402 Standardı'na göre kalite "bir ürün ya da hizmete, ifade edilmiş ya da edilmemiş ihtiyaçları karşılama", JIS-Japon Standartları Enstitüsü'ne göre kalite, "ürün ya da hizmeti ekonomik nedenlerle üreten ve tüketici isteklerine göre şekillenen üretim sistemi", Amerikan Standartları Enstitüsü'ne göre kalite, "mükemmeli oluşturmanın sistematik bir yaklaşımı" ve Avrupa Yönetim Vakfı'na göre kalite ise "belirli bir malın veya hizmetin tüketici ihtiyaçlarına uygunluk derecesi" olarak tanımlanmıştır (Aydıntan, 2012: 2).

Hizmet kalitesi, çok boyutlu bir kavramdır. Bu nedenle hizmet kalitesi için net bir tanım bulunmamaktadır. Literatürde hizmet kalitesi ile ilgili çeşitli tanımlara rastlamak mümkündür. Bu tanımlamalar içerisinde hizmet kalitesi; "gerçekleşen ve algılanan hizmet düzeyi arasındaki farklılık" olarak öne çıkartılmaktadır (Arora ve Stones, 1996: 24).

Hizmet kalitesinin ölçümü, işletmelerin devamlılığı ve karlığını garanti altına alma adına başvurulması gereken önemli bir çalışmadır. Bu sebeple işletmeler piyasada tutunabilmek ve önemli bir yer oluşturmak için kaliteli hizmet vermenin yollarını aramalı ve sürekli müşteri isteklerine göre kendilerini geliştirmelidirler. $\mathrm{Bu}$ kapsamda sunmuş oldukları hizmetler için çeşitli zamanlarda müşterilerin beklenen ve algilanan hizmet kalitesini belirlemelidirler.

Beklenen hizmet kalitesi, müşterinin ürün veya hizmetlere karşı geliştirdiği tahmin ve inançlarıdır. Müşterilerin hizmetleri değerlendirmesinde beklenen hizmet kalitesi önemli rol oynar ve genellikle müşterinin geçmiş deneyimleri etrafında şekillenir (Ünver, 2015: 33). Beklenen hizmet kalitesinde müşterinin arzuları ve istekleri (Robinson, 1999: 26) reklam, kulaktan kulağa iletişim ya da deneyimlerle oluşan ürün 
performansının tahmin edilen düzeyleri (Bolton ve Drew 1991:3) ve geçmiş yaşantı ve o andaki algılara göre gelecekteki olayların hissedilmesi (Kuzu, 2010: 32) önemlidir.

Algılanan hizmet kalitesi ise müşterilerin hisleri olup memnuniyetlerinin derecesini belirler (Ghobadian, Speller ve Jones, 1994: 50). Hizmetlerin soyut bir yapıya sahip olması nedeniyle hizmet kalitesi yerine algılanan hizmet kalitesi literatürde yaygın olarak kullanılmaktadır (Akbaba ve Kılınç, 2001: 163).

$\mathrm{Bu}$ boyutlandırmalar içerisinde Parasuraman, Zeithalm, ve Berry (1985) tarafından önerilen geliştirilen ve on faktör üzerinden hizmet kalitesi ölçümlemesini öngören SERVQUAL ölçeği, hizmet kalitesi ölçümlerinde sıkça kullanılmakta ve bu ölçek için alt boyutlar şu şekilde öne çıkartılmaktadır:

Güvenilirlik: Firmanın ilk seferde hizmeti doğru sağladığı ve ayrıca firmanın sözlerini yerine getirdiği anlamına gelir. Özellikle fatura doğruluğu, kayıtların doğru tutulması ve belirlenen zamanda hizmeti gerçekleştirmesiyle ilgilidir.

Karşılık Vermek: Çalışanların hizmet sunma isteklilikleri veya hazır olmaları ile ilgilidir. Hizmetin zamanında yapılmasını gerektirir. Bir evrakı hemen postalama, müşteriyi hızlı bir şekilde geri çağırma ve hızlı hizmet vermeyi kapsar.

Yeterlilik: Hizmeti gerçekleştirmek için gerekli bilgi ve beceriye sahip olmak demektir. Örneğin; iletişim personelinin bilgi ve becerisi, operasyonel destek personelinin bilgi ve becerileri, kuruluşun araştırma yeteneği, örneğin, menkul kıymetler brokerliği firması gibi.

Ulaşabilirlik: Erişilebilirlik ve iletişim kolaylığı içerir. Örneğin; hizmete telefonla kolayca erişilebilir (hatlar meşgul değildir ve sizi bekletmezler), hizmet almak için bekleme süresi (örneğin bir bankada) geniş değildir, uygun çalışma saatleri, servis tesisinin elverişli konumu.

Nezaket: Personelin nezaket, saygı, düşünce ve samimiyetini içerir (resepsiyonistler, telefon operatörleri vb. dahil). Tüketici mülkiyeti için düşünme (örn. halı üzerinde çamurlu ayakkabı yok), kamuya açık kişilerin temiz ve düzgün bir şekilde görünmesi.

İletişim: Müşterilerin anladığı ve dinlediği dilde bilgilendirilmesidir. Bu, işletmenin kendi dilini farklı tüketiciler için düzenlemesi gerektiği anlamına gelebilir. Örneğin, iyi eğitim görmüş bir müşteri ile gelişmişlik seviyesini arttırmak ve basit ve açık bir şekilde konuşmak ya da hizmetin kendisini açıklamak, hizmetin kaça mal olacağını açıklamak, hizmet ve maliyet arasındaki dengeyi açıklamak, tüketiciye bir sorunun ele alınacağından emin olmak.

İtibar (Kredibilite): Güvenilirlik, inandırıcılık ve dürüstlüğü içerir. Müşteriler için en iyi çıkarları vermeyi içerir. Şirket adı, şirket itibarı, irtibat elemanlarının kişisel özellikleri ve müşteriyle olan etkileşimleri itibar sağlamada oldukça etkilidir.

Güvenlik: Tehlike, risk veya şüphe özgürlüğüdür. Örneğin, fiziksel güvenlik (Otomatik para çekme makinesinde soyulacak mıyım?), finansal güvenlik (Şirket hisse senetlerinin nerede olduğunu biliyor mu?), gizlilik (Şirketle olan ilişkilerim özel mi?). 
Müşterin Anlaşılması /Bilgilendirilmesi: Müşterinin ihtiyaçlarını anlamaya gayret gösterilmesidir. Örneğin; müşterinin özel gereksinimlerini öğrenme, bireyselleştirilmiş ilgi, düzenli müşteriyi tanımak.

Fiziksel Varlıklar: Fiziksel tesisler, personel görünümü, hizmeti sağlamak için kullanılan araçlar veya teçhizat, plastik bir kredi kartı veya banka dekontu gibi hizmetin fiziki temsilleridir.

\section{Metodoloji}

$\mathrm{Bu}$ çalışma kapsamında veriler iki aşamalı bir süreçte toplanmıştır. Birinci aşamada ilgili literatür taranarak benzer çalışmalardan ikincil verilere ulaşılmıştır. İkinci aşamada ise araştırmaya yönelik birincil verilere ulaşmada anket tekniği kullanılmıştır. Araştırmanın birincil verilerine ulaşmak için Akbaba (2006) tarafından geliştirilen çalışma ölçeği kullanılmıştır. Toplam 29 sorudan oluşan ölçek (Ek-1) Safranbolu özelinde olmak üzere yeniden düzenlenerek araştırmacı tarafından kolayda örneklem yöntemi kapsaminda yüz yüze görüşme tekniği ile Safranbolu'ya ziyaret gerçekleştiren ve konaklama hizmeti alan yerli turistlere Ocak-Haziran 2018 dönemi içerisinde uygulanmıştır. Toplam 500 anket toplanmış ve bu anketlerden 406 tanesinin analiz için uygun olduğuna (Geri dönüş oranı: \%81,2) karar verilmiştir.

Araştırma kapsamında katılımcılardan anket yoluyla toplanan veriler ilk önce, bilgisayar ortamına aktarılarak veri tabanı oluşturulmuştur. Katılımcıların tanımlayıcı özelliklerinin belirlenmesi bağlamında yüzde ve frekans analizine başvurulmuştur. Akabinde veri tabanına ilişkin güvenirlik analizi yapılmıştır. Veriler için güvenilirlik katsayısı Cronbach's Alpha $(\alpha)$ 0,93 olarak tespit edilmiştir. Nunnally \& Bernstein (1994) ölçeğin güvenilir ve geçerli kabul edilebilmesi için Cronbach's Alpha değerinin 0,70'in üzerinde olmasını önermektedir. Araştırma verilerin faktör analizine uygun olup olmadığının belirlenmesi bağlamında Kasier-Meyer-Olkin (KMO) katsayısı ve Barlett Sphericity (Bartlett) testlerine kullanılmıştır. KMO katsayısı 0,88, Bartlett Sphericity testi anlamlılık düzeyinin $p=0,000$ olduğu görülmüştür.

$\mathrm{Bu}$ sonuçlar kapsaminda verilerin faktör analizine uygun olduğuna karar verilmiştir. Faktör analizi kapsamında konaklama hizmet kalitesine yönelik 5 boyuta (fiziksel özellikler, güven, yeterlilik, güvenilirlik ve heveslilik) ulaşılmıştır.

Katılımcıların Safranbolu'daki konaklama hizmetine ilişkin memnuniyetlerinin tanımlayıcı özelliklerine göre karşılaştırılmasında, iki değişkenli gruplarda (cinsiyet ve medeni durum) "Bağımsız Örneklem t-Testi"; ikiden fazla değişkenli gruplarda ise (yaş, eğitim durumu, meslek ve gelir durumu) için “Bağımsız Örneklem Tek Yönlü Varyans Analizi (One Way ANOVA)" analiz sonuçları kullanılmıştır.

SERVQUAL yöntemi kapsaminda konaklama hizmet kalitesi değerlendirmesinde müşterilerin beklenti ve algılarını içeren ifadelere verdikleri puanlar arasındaki farkın hesaplanmasında fark analizi (belli dönemlerde gerçek durum ile beklenen durumu karşılaştırma analizi) kullanılmıştır (Koçoğlu, 2009: 42). 


\section{Bulgular}

$\mathrm{Bu}$ bölümde Safranbolu'daki konaklama işletmelerinden hizmet satın alan müşterilere uygulanan anket kapsamında toplanan verilerin analiz sonuçlarına ilişkin bilgi ve bulgulara yer verilmekte ve araştırma doğrultusunda yorumlanmaktadır.

\subsection{Araştırma Katılımcılarına İlişkin Tanımlayıcı Bilgiler}

Araştırmaya dahil olan katılımcıların demografik özelliklerine (cinsiyet, medeni durum, yaş, eğitim durumu, meslek, gelir durumu) yönelik frekans ve yüzde dağılımlarına ait bilgiler Tablo 1'de gösterilen biçimde tespit edilmiştir.

Tablo 1. Katılımcılara İlişkin Tanımlayıcı Bilgiler $(\mathrm{n}=406)$

\begin{tabular}{|c|c|c|c|c|}
\hline Değişkenler & Gruplar & $\mathrm{f}$ & $\%$ & Kümülatif \% \\
\hline \multirow{2}{*}{ Cinsiyet } & Erkek & 296 & 72,9 & 72,9 \\
\hline & Kadın & 110 & 27,1 & 100,00 \\
\hline \multirow{2}{*}{ Medeni Durum } & Evli & 252 & 62,1 & 62,1 \\
\hline & Bekar & 154 & 37,9 & 100,00 \\
\hline \multirow{5}{*}{ Yaş } & $18-23$ & 38 & 9,4 & 9,4 \\
\hline & $24-29$ & 68 & 16,7 & 26,1 \\
\hline & $30-35$ & 94 & 23,2 & 49,3 \\
\hline & $36-41$ & 108 & 26,6 & 75,9 \\
\hline & 42 ve üstü & 98 & 24,1 & 100,00 \\
\hline \multirow{4}{*}{ Eğitim Durumu } & İlköğretim & 30 & 7,4 & 7,4 \\
\hline & Ortaöğretim & 104 & 25,6 & 33,0 \\
\hline & Önlisans & 122 & 30,0 & 63,1 \\
\hline & Lisans & 150 & 36,9 & 100,00 \\
\hline \multirow{6}{*}{ Meslek } & Memur & 58 & 14,3 & 14,3 \\
\hline & İşçi & 98 & 24,1 & 38,4 \\
\hline & Esnaf & 64 & 15,8 & 54,2 \\
\hline & Emekli & 30 & 7,4 & 61,6 \\
\hline & Ev Hanımı & 18 & 4,4 & 66,0 \\
\hline & Diğer & 138 & 34,0 & 100,00 \\
\hline \multirow{5}{*}{ Gelir Durumu } & 2000 TL ve altı & 68 & 16,7 & 16,7 \\
\hline & 2001-3000 TL & 78 & 19,2 & 36,0 \\
\hline & 3001-4000 TL & 90 & 22,2 & 58,1 \\
\hline & $4001-5000 \mathrm{TL}$ & 80 & 19,7 & 77,8 \\
\hline & 5001 TL ve üstü & 90 & 22,2 & 100,00 \\
\hline
\end{tabular}

Tablo 1 verilerine göre araştırma katılımcılarının \%72,9'u erkek, \%27,1'i ise kadınlardan ve \%62,1'i evli, \%37,9'u bekar katılımcılardan oluşmaktadır. Ankete katılan müşterilerin \%9,4'ü 18-23 yaş aralığında, \%16,7'si 24-29 yaş aralığında, \%23,2'si 30-35 yaş aralığında, \%26,6's1 36-41 yaş aralığında ve \%24,1'i 42 yaş ve üstü kişilerden oluştuğu görülmektedir. Katılımcıların eğitim durumu bakımından ilköğretim mezunu olan müşterilerin katılım oranı $\% 7,4$, ortaöğretim müşterilerinin $\% 25,6$, önlisans mezunu müşterilerin \%30 ve lisans mezunu müşterilerin katılım oranı $\% 36,9$ olarak belirlenmiştir. Müşterilerin meslekleri; memur \%14,3, işçi \%24,1, esnaf \%15,8, emekli $\% 7,4$, ev hanımı \%4,4 ve diğer mesleklere mensup müşteriler \%34 olarak tespit 
edilmiştir. Gelir durumu değişkeninde ise 2000 TL ve altı \%16,7, 2001-3000 TL \%19,2, 3001-4000 TL \%22,2, 4001-5000 TL \%19,7 ve 5001 TL ve üstü geliri olan müşterilerin $\% 22,2$ oranında araştırmaya dahil olmuşlardır. Tablo 1 kapsamında demografik özellikleri açısından cinsiyet yönünden erkekler, medeni durum bakımından evli, yaş bakımından 36-41 yaş aralığı; eğitim durumu bakımından lisans mezunları, meslek bakımından diğer meslek sahibi müşterilerin ve gelir durumu açısından 3001-4000 TL ve 5001 TL ve üstü müşterilerin öne çıktığını söylemek mümkündür.

\subsection{Araştırma Ölçeklerine İlişkin Faktör Analizi Bulguları}

Anket tekniği kapsamında elde edilen verilerin araştırma soruları çerçevesinde test edilebilmesi için güvenirlik ve faktör analizi öngörülmüştür. Bu aşamada ilk olarak verilerin faktör analizine uygun olup olmadığını belirlemek için Kasier-Meyer-Olkin (KMO) Örneklem Ölçüm Yeterliliği ve Barlett Sphericity (Bartlett) Küresellik anlamlılık testlerine başvurulmuştur. Yapılan hesaplama sonucunda KMO katsayısı 0,88, Bartlett Sphericity testi anlamlılık düzeyi; $\mathrm{p}=0,000$ tespit edildiği için verilerin faktör analizine uygun olduğuna karar verilmiştir. Büyüköztürk (2007), bir araştırmada güvenilirlik katsayısını 0,70 ve üzeri olmasına, KMO değerinin 0,60'tan büyük ve Bartlett testinin anlamlı çıkmasının gerekliliğine dikkat çekmektedir. Faktör ve güvenirlik analizi sonucunda varyans açılama oranı; 72,30 ve güvenirlilik kat sayısı; 0,88 olarak belirlenmiştir (Tablo 2). Scherer vd. (1988) göre, bu oranın 0,50'den yüksek olması analizin geçerli olduğunu yönündedir.

Tablo 2. Konaklama Hizmeti Alan Turistlerin Hizmet Kalitesi Beklentilerine Yönelik Faktör Analizi

\begin{tabular}{|l|c|c|c|c|c|}
\hline \multicolumn{1}{|c|}{ Faktör } & $\bar{x}$ & $\sigma$ & $\begin{array}{c}\text { Faktör } \\
\text { Yükü }\end{array}$ & $\begin{array}{c}\text { Cronbach } \\
\text { Alpha }\end{array}$ & $\begin{array}{c}\text { Varyans } \\
\text { Açıllama }\end{array}$ \\
\hline Fiziksel Özellikler & $\mathbf{4 , 2 9}$ & $\mathbf{0 , 7 6}$ & & $\mathbf{0 , 9 2 2}$ & $\mathbf{1 8 , 4 5 1}$ \\
\hline $\begin{array}{l}\text { Otelin servis birimleri (yemek odaları, } \\
\text { toplantı odaları yüzme havuzları, iş } \\
\text { merkezi tesisleri vb.) yeterli kapasiteye } \\
\text { sahip bulunmalıdır. }\end{array}$ & 4,23 & 0,88 & 0,813 & & \\
\hline $\begin{array}{l}\text { Otelde modern görünümlü ekipmanlar } \\
\text { (klima, mobilya, asansör, iletişim cihazları } \\
\text { vb.) bulunmalıdır. }\end{array}$ & 4,34 & 0,82 & 0,802 & & \\
\hline $\begin{array}{l}\text { Otel görsel açıdan çekici binalar ve } \\
\text { olanaklara sahip bulunmalıdır. }\end{array}$ & 4,18 & 0,94 & 0,788 & & \\
\hline $\begin{array}{l}\text { Otelin donanımı (yataklar, sandalyeler, } \\
\text { odalar vb.) konaklama amacına uygun ve } \\
\text { konforlu (rahat, temiz ve huzurlu) } \\
\text { olmalıdır. }\end{array}$ & 4,33 & 0,85 & 0,781 & & \\
\hline $\begin{array}{l}\text { Otelin donanımı arızalara neden olmadan } \\
\text { düzgün çalışır olmalıdır. }\end{array}$ & 4,36 & 0,84 & 0,732 & & \\
\hline
\end{tabular}


Tablo 3. Konaklama Hizmeti Alan Turistlerin Hizmet Kalitesi Beklentilerine Yönelik Faktör Analizi (Devamı)

\begin{tabular}{|c|c|c|c|c|c|}
\hline Faktör & $\bar{x}$ & $\sigma$ & $\begin{array}{l}\text { Faktör } \\
\text { Yükü }\end{array}$ & $\begin{array}{c}\text { Cronbach } \\
\text { Alpha }\end{array}$ & $\begin{array}{c}\text { Varyans } \\
\text { Açıllama }\end{array}$ \\
\hline Güven & 4,48 & 0,56 & & 0,878 & 15,311 \\
\hline $\begin{array}{l}\text { Otel çalışanları misafirlere güven verici } \\
\text { olmalıdır. }\end{array}$ & 4,48 & 0,66 & 0,833 & & \\
\hline $\begin{array}{l}\text { Otel, sunduğu imkânlar ve hizmetler } \\
\text { hakkında bilgi verici (yön levhaları, telefon, } \\
\text { internet vb. yollarla bilgi sağlamalı) } \\
\text { olmalıdır. }\end{array}$ & 4,54 & 0,62 & 0,793 & & \\
\hline $\begin{array}{l}\text { Otel, kolaylıkla erişilebilir (ulaşım, otopark } \\
\text { alanı yükleme ve boşaltma alanı, vs.) } \\
\text { olmalıdır. }\end{array}$ & 4,47 & 0,70 & 0,767 & & \\
\hline $\begin{array}{l}\text { Otel, konuklarına güvenli ve emniyetli bir } \\
\text { konaklama sağlamalıdır. }\end{array}$ & 4,42 & 0,65 & 0,739 & & \\
\hline Yeterlilik & 4,37 & 0,63 & & 0,855 & 13,967 \\
\hline $\begin{array}{l}\text { Otel, konukların yaşadığı sıkıntıları ve } \\
\text { şikâyetlerini gidermelidir. }\end{array}$ & 4,45 & 0,69 & 0,797 & & \\
\hline $\begin{array}{l}\text { Otel, konuk taleplerine göre hizmetlerde } \\
\text { esneklik sağlamalıdır. }\end{array}$ & 4,32 & 0,75 & 0,723 & & \\
\hline $\begin{array}{l}\text { Otel, tutarlı hizmetler (her seferinde aynı } \\
\text { hizmetleri benzer şekilde) sunmalıdır. }\end{array}$ & 4,28 & 0,84 & 0,719 & & \\
\hline $\begin{array}{l}\text { Otel, kayıtlarını (rezervasyonlar, misafir } \\
\text { bilgileri, faturalar, siparişler, vb.) doğru } \\
\text { tutmalıdır. }\end{array}$ & 4,43 & 0,74 & 0,704 & & \\
\hline \begin{tabular}{|l|} 
Güvenilirlik \\
\end{tabular} & 4,38 & 0,62 & & 0,858 & 13,047 \\
\hline $\begin{array}{l}\begin{array}{l}\text { Otelin çalışanları } \\
\text { (üniforma vüzgün }\end{array} \text { ve düzenli } \\
\text { görünmelidir. }\end{array}$ & 4,31 & 0,76 & 0,783 & & \\
\hline $\begin{array}{l}\text { Hizmetlerle ilişkili malzemeler (sabun, } \\
\text { şampuan, havlu vb.) yeterli olmalıdır. }\end{array}$ & 4,42 & 0,75 & 0,769 & & \\
\hline $\begin{array}{l}\text { Verilen yiyecek ve içecek hizmetleri } \\
\text { hijyenik, yeterli olmalıdır. }\end{array}$ & 4,41 & 0,74 & 0,748 & & \\
\hline Otel, söz verdiği hizmetleri sunmalıdır. & 4,37 & 0,74 & 0,621 & & \\
\hline Heveslilik & 4,23 & 0,67 & & 0,771 & 11,533 \\
\hline $\begin{array}{l}\text { Otel çalışanları konukların özel ihtiyaçlarını } \\
\text { anlamalıdır. }\end{array}$ & 4,17 & 0,95 & 0,863 & & \\
\hline $\begin{array}{l}\text { Otel çalışanları her zaman konuklara } \\
\text { arkadaşça davranmalıdır. }\end{array}$ & 4,15 & 0,90 & 0,795 & & \\
\hline $\begin{array}{l}\text { Otel ve tesisleri, tüm konukları için uygun } \\
\text { çalışma saatlerine sahip bulunmalıdır. }\end{array}$ & 4,30 & 0,80 & 0,554 & & \\
\hline $\begin{array}{l}\text { Otel çalışanları, konuklara kendilerini özel } \\
\text { hissettiren bir düzeyde ilgi göstermelidir. }\end{array}$ & 4,32 & 0,80 & 0,540 & & \\
\hline Cronbach Alpha/Varyans Açıklama (\%) & & & & 0,932 & 72,308 \\
\hline
\end{tabular}

K-M-O Örneklem Ölçüm Yeterliliği: 0,88

Bartlett's Küresellik Testi (Chi-Square / df / Sig): 5885,674/ 210 / 0,000 
Tablo 2' de görüldüğü üzere konaklama hizmeti alan turistlerin hizmet kalitesi beklentilerinde beş boyuta (fiziksel özellikler, güven, yeterlilik, güvenilirlik, heveslilik) ulaşılmıştır. Beklenti öncelikleri Fiziksel Özellikler, Güven, Yeterlilik, Güvenilirlik, Heveslilik sırasında tespit edilmiştir.

\subsection{SERVQUAL Yöntemine Göre Safranbolu'da Sunulmakta Olan Konaklama Hizmeti Kalitesinin Ölçümü}

Araştırmada örnek alan olarak seçilen Safranbolu'daki konaklama işletmeleri tarafından sunulan hizmetlere ilişkin turistlerin algılanan ve beklenen hizmet kalitelerine yönelik beş alt boyut (fiziksel özellikler, güven, yeterlilik, güvenilirlik, heveslilik) için SERVQUAL skorları Tablo 3'te gösterilen biçimde hesaplanmıştır:

Tablo 4. Safranbolu'da Sunulmakta Olan Konaklama Hizmetine İlişkin SERVQUAL Skoru

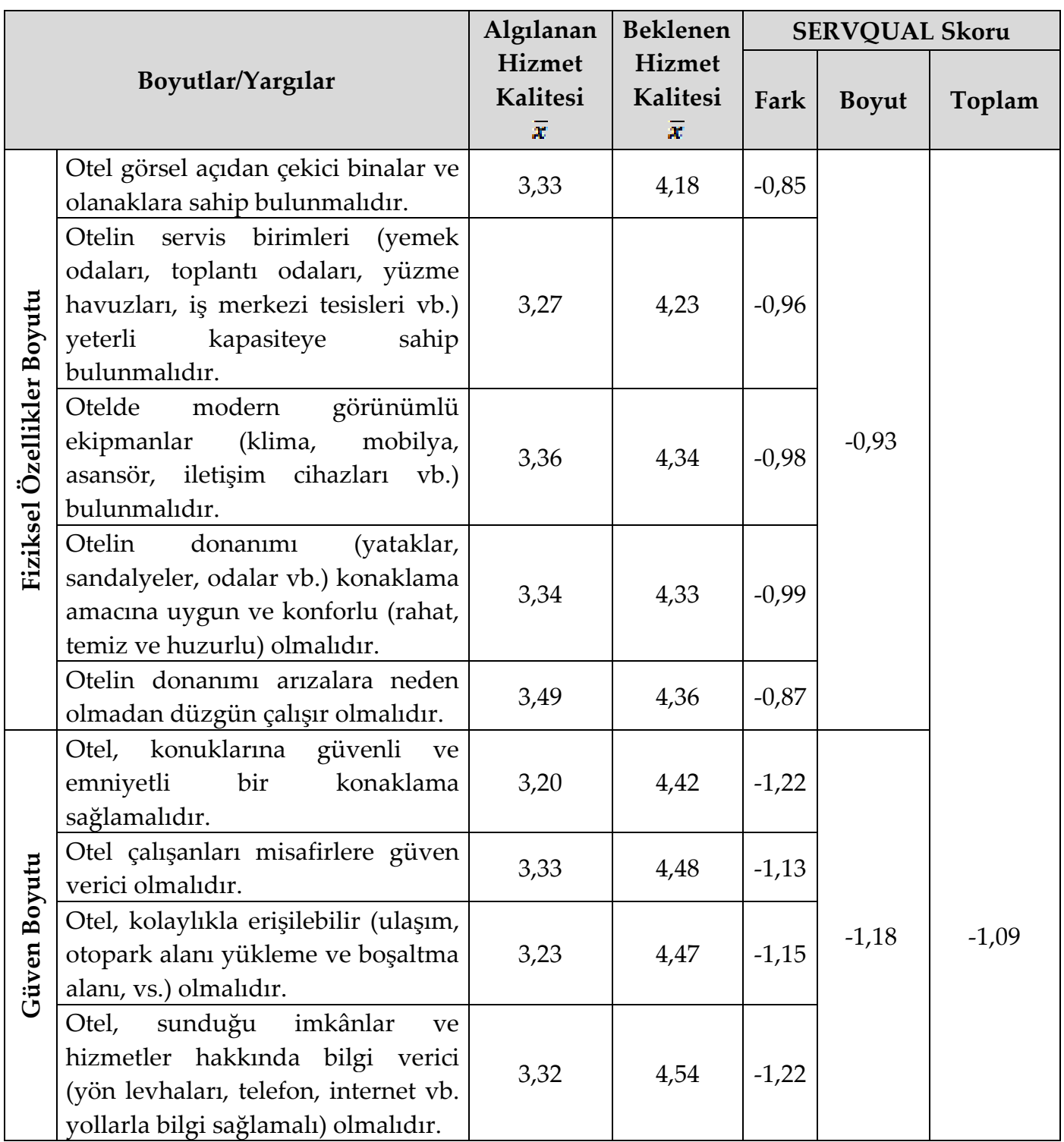


Tablo 5. Safranbolu'da Sunulmakta Olan Konaklama Hizmetine İlişkin SERVQUAL Skoru (Devamı)

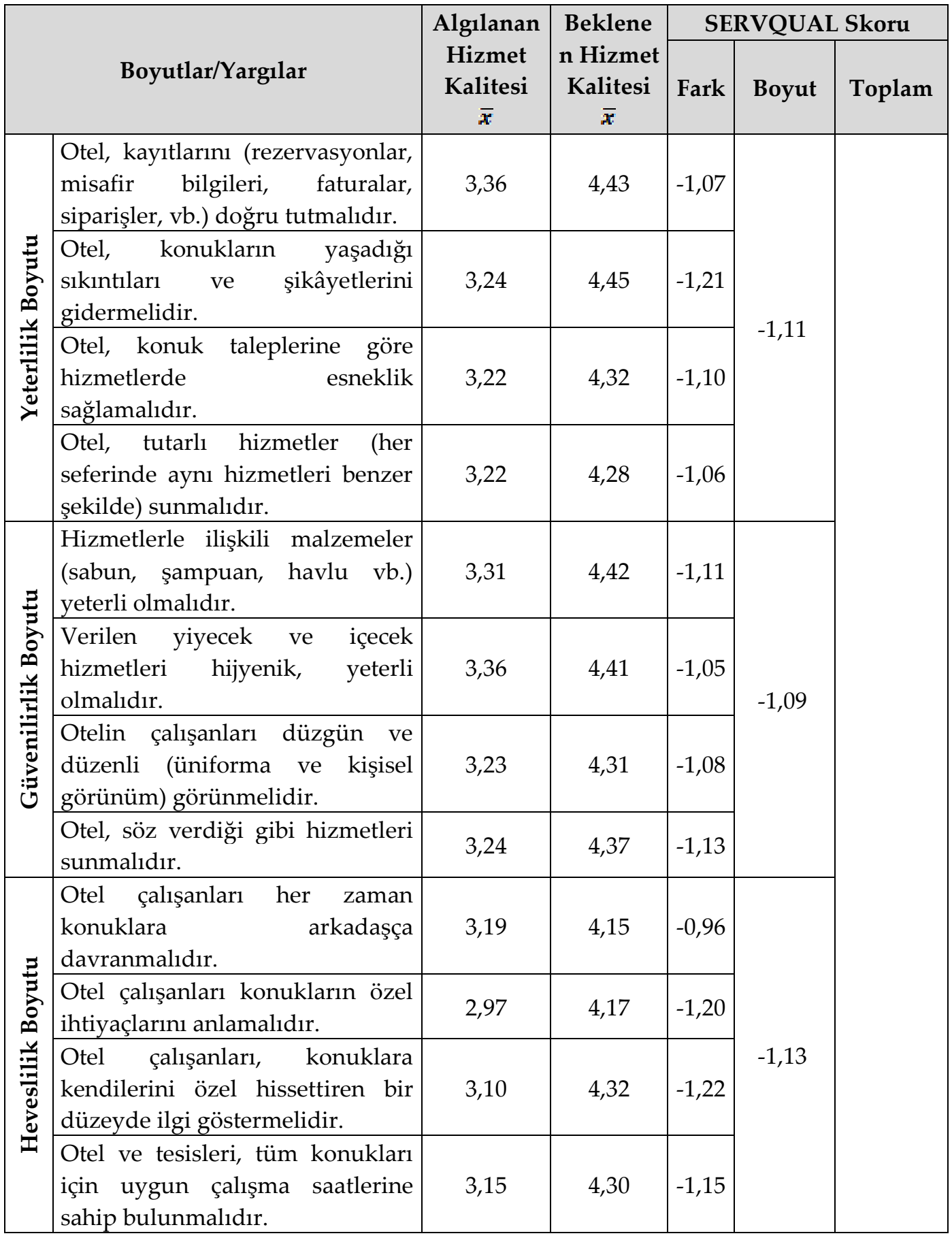

Tablo 3 çerçevesinde konaklama işletmeleri tarafından sunulan hizmetlerin kalitesini belirlemeye yönelik boyutlar yapısal olarak incelendiğinde;

Fiziksel özellikler alt boyutunda yerli turistlerin beklenen ve algilanan hizmet kalitelerine ilişkin SERVQUAL skorunda en büyük fark, -0,99 puan ile "otelin donanımı (yataklar, sandalyeler, odalar vb.) konaklama amacina uygun ve konforlu (rahat, temiz ve huzurlu) olmalıdır" ifadesinde çıkmıştır. Bunu "otelde modern 
görünümlü ekipmanlar (klima, mobilya, asansör, iletişim cihazları vb.) bulunmalıdır." yarg1sı $(-0,98)$ izlemektedir. Bu durumlar kapsamında müşterilerin otel odasında yer alan donanımlarının düzgün çalışır olmasını ve rahatlıklarını önemsedikleri söylenebilir. Bununla birlikte hizmet kalitesi fiziksel özellikler boyutuna ilişkin beş ifadenin SERVQUAL skor ortalamasınin negatif $(-0,93)$ olmasi Safranbolu'daki konaklama işletmelerinin fiziksel özellikler beklentilerini karşılamadığı ve konaklama işletmelerinin bu yönde fiziksel inovasyona ihtiyaç duyduğunu söylemek yerinde olacaktır.

Güven alt boyutunda yerli turistlerin beklenen ve algılanan hizmet kalitelerine ilişkin SERVQUAL skorunda en büyük fark, -1,22 puan ile "otel, konuklarına güvenli ve emniyetli bir konaklama sağlamalıdır" ve "otel, sunduğu imkânlar ve hizmetler hakkında bilgi verici (yön levhaları, telefon, internet vb. yollarla bilgi sağlamalı) olmalıdır" yargılarında ortaya çıkmıştır. Bu sonuçlara göre turistlerin otelin güvenliğini ve kalış süreleri boyunca imkanlar hakkında bilgilendirmeyi önemsemektedirler. Safranbolu destinasyonu için konaklama hizmeti güven boyutuna ilişkin SERVQUAL skor ortalamasının negatif olması $(-1,18)$ kapsamında konaklama işletmelerinin turistlerin güven beklentilerini karşılamada yetersiz kaldığı ve destinasyondaki işletmelerin bu yönde kendilerini geliştirmesi gerektiği şeklinde yorumlanabilir.

Yeterlilik alt boyutunda yerli turistlerin beklenen ve algilanan hizmet kalitelerine ilişkin SERVQUAL skorunda en büyük fark, -1,21 puan ile "otel, konukların yaşadığı sıkıntıları ve şikâyetlerini gidermelidir" yargısında ortaya çıkmıştır. SERVQUAL skorunda öne çıkan diğer bir yargı ise -1,10 skor puanı ile "otel, konuk taleplerine göre hizmetlerde esneklik sağlamalıdır" yargısı olmuştur. Bununla birlikte yeterlilik alt boyutuna ilişkin dört ifadenin SERVQUAL skor ortalamasının 1,11 kapsamında da Safranbolu'daki konaklama işletmelerinin yeterlilik beklentilerini karşılayamadığı şeklinde algılanabilir.

Güvenilirlik alt boyutunda yerli turistlerin beklenen ve algılanan hizmet kalitelerine ilişkin SERVQUAL skorunda en büyük fark -1,13 puan ile "otel, söz verdiği gibi hizmetleri sunmalıdır" yargısında görülmüştür. Bu yargıyı -1,11 SERVQUAL skoruyla "hizmetlerle ilişkili malzemeler (sabun, şampuan, havlu vb.) yeterli olmalıdır." yargısı izlemektedir. Bu yargılar kapsamında otel müşterilerin verilen sözlerin tutulmasını ve hizmetlerle ilişkili malzemelerin tam olmasını önemsediklerini söylemek mümkündür. Safranbolu'daki konaklama hizmetlerine yönelik güvenilirlik boyutunda yer alan tüm yargıların puan skorların negatif olması ve SERVQUAL skor ortalamasının da negatif olması $(-1,09)$ kapsamında Safranbolu'daki konaklama işletmelerinin güvenilirlik beklentilerini karşılamada yetersiz kaldığ 1 şeklinde değerlendirilebilir.

Heveslilik alt boyutunda yerli turistlerin beklenen ve algilanan hizmet kalitelerine ilişkin SERVQUAL skorunda en büyük fark -1,22 puan ile "otel çalışanları, konuklara kendilerini özel hissettiren bir düzeyde ilgi göstermelidir" ve -1,20 puanla "otel çalışanları konukların özel ihtiyaçlarını anlamalıdır" yargılarında ortaya 
çıkmıştır. Heveslilik boyutuna ilişkin ortalama SERVQUAL skor puanın negatif olması $(-1,13)$ kapsamında Safranbolu'daki konaklama işletmelerinin heveslilik beklentilerini karşılamada fiziksel özellikler, güven, yeterlilik ve güvenilirlik alt boyutlarında olduğu gibi karşılanmadığı söylenebilir.

Safranbolu'daki konaklama işletmeleri tarafından sunulan konaklama hizmetine ilişkin tüm boyutlara (fiziksel özellikler, güven, yeterlilik, güvenilirlik, heveslilik,) yönelik beklenen ve algılanan SERVQUAL skorlarını incelendiğinde en fazla fark -1,18 puanla güven alt boyutunda, en düşük fark ise -0,93 puanla fiziksel özellikler alt boyutunda ortaya çımıştır. Diğer sıralamalar ise heveslilik $(-1,13)$, yeterlilik $(-1,11)$ ve güvenilirlik $(-1,09)$ önceliğinde tespit edilmiştir. Destinasyon için tüm boyutların SERVQUAL skoru ortalamasının -1,09 olarak ortaya çıkması bağlamında kültür turizmi ve son dönemlerde doğa turizmi ile öne çıkan bir varış noktası olan Safranbolu için konaklama hizmeti sunan işletmelerin birtakım önlemleri alması ve kendini geliştirmesi gerektiğini söyleyebiliriz. Bu durumlara yönelik yapılacak iyileştirmeler çerçevesinde konaklama hizmeti için yeniden hizmet kalitesi ölçümüne gidilmesi halinde SERVQUAL skorun pozitif değerlere yaklaşması olasıdır.

\section{Sonuçlar ve Öneriler}

Turizm bölgelerindeki konaklama hizmetleri, destinasyonların rekabet gücünün temelini oluşturur. Çünkü konaklama, turizm ekonomisindeki en büyük ve en yaygın alt sektördür. Birkaç istisna dışında, turistlerin bir destinasyonu ziyaretlerinde dinlenebilecekleri ve rahatlayabilecekleri bir yere ihtiyaç duyması bu sektörü öne çıkarır. Otelcilik sektörünün bir bileşeni olarak konaklamada misafirlerin konaklama şekline göre ilişkili hizmetlere ve yiyecek ve içeceğe bir ücretin ödenmesi bu sektörün odak noktasını oluşturur. Bir destinasyonda konaklamanın gelişmesi, o destinasyonda turizm gelişimini ve turizm talebini artırır (Cooper vd., 2008; Page, 2009).

Bir destinasyonda konaklama işletmeleri sermaye ve emek yoğunluğu ile öne çıkan işletmelerdir. Bu işletmelerin kuruluşu, büyük bir sermaye yapısını ve işletilmesi de çok sayıda personelin eşgüdümünü gerektirir. Bununla birlikte turizm ürünün bir parçası olan konaklamada işletmenin kuruluş yeri, tesisleri, hizmet seviyesi, piyasadaki imajı ve fiyatları kapsayan karmaşık bir kombinasyonudur (Page, 2016; Magombo, Rogerson, \& Rogerson, 2017). Pazar, fiyat, konum ve kalite gibi belirleyici faktörlerle ilgilenen, farklı ihtiyaçlara sahip misafirler için segmentlere ayrılabilir (Goss-Turner, 2000). Bu nedenle konaklama işletmelerine yönelik bilimsel araştırmalar, değerli çalışmalar olarak görülebilir.

Türkiye özelinde konaklama sektörüne yönelik önceki çalışmalarda; otel işletmelerinde hizmet kalitesi (Çatı, Koçoğlu ve Gelibolu, 2010) ve işgörenlerin hizmet kalitesi algılamaları (Buyruk, 1999); konaklama işletmelerinde kat hizmetleri yöneticilerinin hizmet kalitesine yönelik algılarının belirlenmesi (Erdem, 2010); analitik hiyerarşi süreci yöntemi ile otel işletmelerinde hizmet kalitesini değerlendirme (Murat ve Çelik, 2007); konaklama işletmelerinde sunulan hizmet kalitesinin servqual yöntemi ile ölçülmesi (Öztürk ve Seyhan, 2005); konaklama işletmelerinde hizmet kalitesinin 
ölçümünde kullanılan modeller (Temizel ve Garda, 2017); hizmet kalitesi ve otel işletmelerinde servqual uygulamaları (Akbaba ve Kılınç, 2001); turizm sektöründe servqual analizi ile hizmet kalitesinin ölçülmesi ( Eleren ve Kılıç, 2007); termal otel işletmelerinde hizmet kalitesinin ölçülmesi ( K1lıç ve Eleren, 2010) araştırılmıştır.

$\mathrm{Bu}$ araştırma, ulusal ve uluslararası düzeyde tanınan bir destinasyon olan Safranbolu'daki konaklama hizmet kalitesinin değerlendirilmesine yönelik tasarlanmış olup; Safranbolu'ya ziyaret gerçekleştiren yerli turistlerin görüşleri perspektifinden destinasyon düzeyinde beklenen ve algılanan hizmet kalitesi ölçümü ile müşteri memnuniyetinin ortaya çıkarılmasını amaçlamaktadır. Araştırma amacı kapsamında Safranbolu ilçesine ziyaret gerçekleştiren ve konaklama hizmeti alan 406 yerli turistten sağlanan veriler kapsamında turistlerin demografik ve diğer özellikleri ile beklenen hizmet kalitesi algıları arasında anlamlı bir farklığının bulunup bulunmadığı ve Safranbolu destinasyonu için konaklama hizmetleri boyutunda Ocak ve Haziran 2018 için beklenen ve algılanan hizmet kalitesi arasındaki SERVQUAL skoru hesaplanmış olup şu sonuçlara ulaşılmıştır:

-Safranbolu'ya ziyaret gerçekleştiren yerli turistler demografik özelliklerinde cinsiyet yönünden erkekler, medeni durum bakımından evliler, yaş bakımından 36-41 yaş aralığı; eğitim durumu bakımından lisans mezunları, meslek bakımından diğer meslek sahipleri ve gelir durumu açısından 3001-5001 TL gelire sahip bulunanlar öne çıkmıştır.

-Turistlerin beklenen konaklama hizmeti algısında fiziksel özellikler, güven, yeterlilik, güvenilirlik ve heveslilik olmak üzere beş boyuta ulaşılmıştır. Bu boyutlar için beklenti önceliklerinin fiziksel özellikler, güven, yeterlilik, güvenilirlik ve heveslilik sırasında olduğu tespit edilmiştir.

-Fiziksel özelikler boyutunda turistlerin otelin donanımının arızalara neden olmadan düzgün çalışmasını, otelin modern görünümlü ekipmanlara (klima, mobilya, asansör, iletişim cihazları vb.) sahip bulunmasını ve otelin donanımının (yataklar, sandalyeler, odalar vb.) konaklama amacına uygun ve konforlu (rahat, temiz ve huzurlu) olmasını önemsedikleri belirlenmiştir. Güven boyutuna yönelik hizmet kalitesinde turistlerin beklentileri otel, sunduğu imkânlar ve hizmetler hakkında bilgi vermesi, otel çalışanları misafirlere güven verici davranışlar sergilemesi öne çıkmıştır. Yeterlilik boyutuna yönelik hizmet kalitesinde otelin konukların yaşadığı sıkıntıları ve şikâyetlerini gidermesi, kayıtlarını (rezervasyonlar, misafir bilgileri, faturalar, siparişler, vb.) doğru tutması, konuk taleplerine göre hizmetlerde esneklik sağlaması ve her seferinde aynı hizmetleri benzer şekilde sergilemesi beklenmektedir. Hizmet kalitesi güvenilirlik boyutunda konaklama hizmeti ile ilişkili malzemelerin (sabun, şampuan, havlu vb.) yeterli olması, yiyecek ve içecek hizmetlerinde hijyeniklik ve otelin söz verdiği gibi hizmetleri sunması arzulanmaktadır. Heveslilik boyutunda ise otel çalışanları, konuklara kendilerini özel hissettiren bir düzeyde ilgi göstermesinin öne çıkarıldı̆̆ı tespit edilmiştir.

-Safranbolu destinasyonu için konaklama hizmetine ilişkin beklenen ve algılanan hizmet kalitesi için SERVQUAL skorlarında en fazla fark -1,18 puanla güven 
alt boyutunda, en düşük fark ise $-0,93$ puanla fiziksel özellikler alt boyutunda ortaya çıkmıştır. Destinasyon konaklama SERVQUAL skoru ortalaması ise -1,09 olarak belirlenmiştir. SERVQUAL skorunun negatif olması bağlamında konaklama hizmetlerinin bazı düzenlemelere ihtiyacının bulunduğu şeklinde değerlendirilebilir.

$\mathrm{Bu}$ sonuçlar kapsamında Safranbolu'da sunulmakta olan konaklama hizmetlerinin kalitesinin yükseltilmesi kapsamında şu öneriler yapılabilir:

- Konaklama işletmeleri sundukları hizmetleri analiz ederek her hizmet için standart oluşturulmalı ve hizmet sunmakta olan işgörenlerini bu standartlar hakkında bilgilendirilmeli,

- Destinasyon düzeyinde belirli periyotlarda konaklama hizmetlerine ilişkin kalite ölçümleri yapılmalı ve bu ölçümlerde İl Kültür Turizm Müdürlüğü ve Belediye öncülük rolü üstlenmelidir. Ölçüm sonuçlarını ilgili destinasyon paydaşlarını bilgilendirilmeli,

- Konaklama sektöründe çalışan işgörenler, sezon dişı dönemlerde turizm hizmetleri kapsamında eğitime alınabilir. Bu konuda Safranbolu ilçesinde bulunmakta olan üniversite birimlerinden faydalanabilir,

- Konaklama işletmeleri turistlerin beklentileri doğrultusunda fiziksel ortam inovasyonuna yönelmeyi ilke edinmeli ve misafirleri için konforlu ortamlar yaratılmalidir,

- Konaklama işletmeleri, tesislerinde çalıştıracağı personeli belirlemede seçici olmalı nitelikli personel çalıştırmalıdır,

- Ulusal ve uluslararası olmak üzere Safranbolu destinasyonu dışındaki konaklama işletmelerindeki uygulamalar takip edilmeli ve yenilikler destinasyona taşınmalıdır.

$\mathrm{Bu}$ araştırmada, Safranbolu destinasyonu özelinde konaklama işletmeleri tarafından sunulmakta olan hizmetlerin kalitesine yönelik bir kavramsal çerçeve oluşturulmuştur. Araştırmanın Türkiye'deki Safranbolu'ya benzer destinasyonlar için yol gösterici olması beklenmektedir. Bununla birlikte bu çalışma Ocak-Haziran dönemi kapsamında seyahate çıan turistler üzerinde gerçekleştirilmiştir. Gelecekteki çalışmalarda farklı zaman dilimlerinde ölçüm yapılması, yabancı turistlere yönelik olması farklı öngörüler oluşturabilir.

\section{Kaynakça}

Akbaba, A. (2006). Measuring service quality in the hotel industry: A study in a business hotel in Turkey. International Journal of Hospitality Management, (25), 170-192.

Akbaba, A. ve Kılınç, İ. (2001). Hizmet kalitesi ve turizm işletmelerinde SERVQUAL uygulamaları. Anatolia: Turizm Araştırmaları Dergileri, (12), 162-168.

Al-Ababneh, M. (2013). Service quality and its impact on tourist satisfaction. Interdisciplinary Journal of Contemporary Research in Business, 4(12), 164-177.

Al-Ababneh, M. (2017). Service quality in the hospitality industry. [Online] https://www.researchgate.net/publication/316881857_Service_Quality_in_the_Hospitali ty_Industry> Erişim Tarihi: 01.12.2018. 
Arakaya, A. (2016). Üniversite Öğrencilerinin Hizmet Kalitesi Algılarının Ölçümü: Karabük Üniversitesi Örneği. Yayınlanmamış Yüksek Lisans Tezi, Karabük Üniversitesi, Sosyal Bilimler Enstitüsü, Karabük.

Arora, R. ve Stones, C. (1996). The effects of perceived service quality and name familiarity on the service selection decision. The Journal of Service Marketing, 10(1), 22-34.

Arslantürk, Y., Altunöz, Ö. ve Çalık, A. Ö. (2013). Turist rehberliği hizmet kalitesi ölçümü: SERVQUAL yaklaşımı. Uluslararası Sosyal Araştırmalar Dergisi, 6(27), 107-118.

Aydıntan, B. (2012). Kalitenin Temelleri. Tuna, M. ve Güler, İ. (Ed.), Kalite Yönetim Sistemleri (s. 1-19). Ankara: Detay Yayıncilik.

Bolton, R. N. ve Drew, J. H. (1991). A longitudinal analysis of the impact of service changes on customer attitudes. Journal of Marketing, 55(1), 1-9.

Buyruk, L. (1999). Otel İşletmelerinde Hizmet Kalitesi ve Otel İşgörenlerinin Hizmet Kalitesini Algılamaları Konusunda Bir Araştırma. Yayınlanmamış Doktora Tezi, Marmara Üniversitesi, Sosyal Bilimler Enstitüsü, İstanbul.

Cooper, C., Fletcher, F. A., Gilbert, D. \& Wanhill, S. (2008). Tourism Principles and Practice (4th ed.) Essex: Prentice Hall.

Çatı, K., Koçoğlu, C. M. ve Gelibolu, L. (2010). Müşteri beklentileri ile müşteri sadakati arasındaki ilişki: Beş yıldızlı bir otel örneği. Ç.Ü. Sosyal Bilimler Enstitüsü Dergisi, 19(1), $429-446$.

Eleren, A. ve Kılıç, B. (2007). Turizm sektöründe servqual analizi ile hizmet kalitesinin ölçülmesi ve bir termal otelde uygulama. Afyon Kocatepe Üniversitesi, İ̈BF Dergisi, 9(1), 235-263.

Erdem, B. (2010). Kat hizmetleri yöneticilerinin hizmet kalitesi algıları: konaklama işletmelerinde görgül bir araştırma. Ç.Ü. Sosyal Bilimler Enstitüsü Dergisi, 19(3), 165-182.

Ghobadian, A., Speller, S. ve Jones, M. (1994). Service quality: Concepts and models. International Journal of Quality \& Reliability Management, 11(9), 43-66.

Goss-Turner, S. (2000). Encyclopedia of Tourism. J. Jafari (Ed). London, GBR: Routledge.

Gürbüz, A. ve Doğan, M. (2013). Tüketicilerin markaya duyduğu güven ve marka bağl1lığ ilişkisi. Uluslararası Yönetim İktisat ve İsletme Dergisi, 9(19), 239-258.

http://dictionary.com/browse/lodging> [Erişim Tarihi: 15.12.2017].

http://resmigazete.gov.tr/eskiler/2005/06/20050621-11.htm> [Erişim Tarihi: 15.12.2017].

http://smallbusiness.chron.com/organizational-structure-hotel-3809.html [Erişim Tarihi: 16.03.2018].

https://google.com.tr/search?ei=53AzWuioGKuQ6QTqZG4Dg\&q=lodging+definition\&oq=LODG\%C4\%B0NG+DEF\%C4\%B0NAT\%C4\%B0O N\&gs_l=psyab.1.0.0i19k113j0i13i30i19k113j0i13i5i30i19k114.7925.7925.0.9454.1.1.0.0.0.0.161.161.0j1.1.0. ...0...1.1.64.psy-ab..0.1.160....0.5N6hBy-2XCo> [Erişim Tarihi: 15.12.2017].

https://merriam-webster.com/dictionary/lodging> [Erişim Tarihi: 15.12.2017]. 
Kılıç, B.ve Eleren, A. (2010). Termal otel işletmelerinde hizmet kalitesinin ölçülmesi, Süleyman Demirel Üniversitesi İktisadi ve İdari Bilimler Dergisi, 15(3), 119-142.

Koçoğlu, C. M. (2009) Hizmet Kalitesinin Müşteri Sadakati Üzerindeki Etkisi ve Beş Yıldızlı Bir Otel İşletmesinde Uygulama. Yayınlanmamış Yüksek Lisans Tezi, Düzce Üniversitesi, Sosyal Bilimler Enstitüsü, Düzce.

Kotler, P. (2000). Pazarlama Yönetimi. Çev.: N. Muallimoğlu, İstanbul: Beta Basım Yayın.

Kuzu, A. (2010) Yaşlı Bakım Kurumlarında Hizmet Kalitesi Kavramı ve Kavramsal Hizmet Kalitesi Modeli: SERVQUAL Uygulaması. Yayınlanmamış Doktora Tezi, Sakarya Üniversitesi, Sosyal Bilimler Enstitüsü, Sakarya.

Magombo, A., Rogerson, C. M. \& Rogerson, J. M. (2017). Accommodation services for competitive tourism in Sub-Saharan Africa: Historical evidence from Malawi. Bulletin of Geography Socio-economic Series (38), 73-92.

Murat, G. ve Çelik, N. (2007). Analitik hiyerarşi yöntemi ile otel işletmelerinde hizmet kalitesini değerlendirme: Bartın örneği. ZKÜ Sosyal Bilimler Dergisi, 3(6), 1-20.

Nunnally, J. C. and Bernstein, I. H. (1994). The Assessment of Reliability. Psychometric Theory, ABD: McGraw-Hill.

Odabaşı, Y. ve Barış, G. (2002). Tüketici Davranışı. İstanbul: MediaCat.

Okumuş, A. ve Duygun, A. (2008). Eğitim hizmetlerinin pazarlanmasında hizmet kalitesinin ölçümü ve algılanan hizmet kalitesi ile öğrenci memnuniyeti arasındaki ilişki. Anadolu Üniversitesi Sosyal Bilimler Dergisi, 8(2), 17-38.

Özel, Ç. H., (2016) Otelcilik Endüstrisi. Kozak, A. M. (Ed.), Otel İşletmeciliği (s. 2-17). Ankara: Detay Yayıncilik.

Öztürk, S. ve Seyhan, K. (2005). Konaklama işletmelerinde sunulan hizmet kalitesinin servgual yöntemi ile ölçülmesi. Anatolia: Turizm Araştırmaları Dergisi, 16(2), 170-182.

Page, S. J. (2009). Tourism Management: Managing for Change. New York: Elsevier Ltd.

Page, S. J. (2016). Tourism Management. London: Taylor \& Francis Ltd.

Parasuraman, A., Zeithalm, A. V. ve Berry L. L. (1985). A conceptual model of service quality and its implications for future research. Journal of Marketing, 49(4), 41-50.

Robinson, S. (1999). Measuring service quality: current thinking and future requirements. Marketing İtelligence \& Planing, 17(1), 21-32.

Şimşek, M. (1998). Kalite Yönetimi. İstanbul: Alfa Basım Yayım Dağıtım.

Temizel, G. ve Garda, B. (2017). Konaklama işletmelerinde hizmet kalitesi ve kavramı ve hizmet kalitesinin ölçülmesinde kullanılan modeller. Selçuk Üniversitesi Sosyal ve Teknik Araştırmalar Dergisi, (14), 161-171.

Tütüncü, Ö. (2009). Ağırlama Hizmetlerinde Kalite Sistemleri. Ankara: Detay Yayıncılık.

Üner, M. (1994). Hizmet pazarlamasında pazarlama karması elemanları değişiklik gösterir mi?. Pazarlama Dünyası Dergisi, 8(34), 2-11.

Ünver, A. E. (2015). Mobil Reklamcıllkta Bireysel Müşteri Hizmet Kalitesi ile Müşteri Memnuniyeti İlişkisine Dair Ampirik Bir Çalışma. Yayınlanmamış Yüksek Lisans Tezi, Hitit Üniversitesi, Sosyal Bilimleri Enstitüsü, Çorum. 
A. Gürbüz, N. Ayaz.../ Karabük Üniversitesi Sosyal Bilimler Enstitüsü Dergisi, 2019, 9 (2), 400-417

Yeşiltaş, M. (1998). Otel İşletmelerinde Personel Yönetimi Departmanı. Kozak, N. (Ed.), Otel İşletmeciliği Kavramlar- Uygulamalar (s. 201). Ankara: Turhan Kitabevi Yayınları. 